\title{
Opinion 49 \\ Conservation of the Generic Name Rhodopseudomonas Czurda and Maresch emend: van Niel
}

The generic name Rhodopseudomonas Czurda and Maresch emend. van Niel has been conserved by the Judicial Commission of the International Committee on Systematic Bacteriology.

The validity of the publication of the generic name Rhodopseudomonas Czurda and Maresch 1937 (1) is questionable for lack of a type species and a definite proposal (reference 2, Minute 13, Rules 9c, 12c, 13), but the name has been widely used in the sense of the concept of van Niel (7). van Niel designated Rhodopseudomonas palustris as the type species of Rhodopseudomonas, the same type as that of the disused generic name Rhodobacillus Molisch 1907 (5), which therefore has priority, as pointed out by Pfenning and Truper (6). Pfennig and Truper requested conservation of the name Rhodopseudomonas in the emended sense of van Niel. The Judicial Commission has acceded to this Request (reference 3, Minute 12) and issues the following Opinion under Rule 9c.

Opinion 49. The generic name Rhodopseudomonas Czurda and Maresch 1937 emend. van Niel 1944 is conserved over all earlier objective synonyms; the type species is Rhodopseudomonas palustris (Molisch 1907) van Niel 1944 (basionym: Rhodobacillus palustris Molisch 1907).

\section{LITERATURE CITED}

1. Czurda V., and N. Maresch. 1937. Beitrag zur Kenntnis der Athiorhodobakterien-Gesellschaft. Arch. Mikrobiol. 8:99-124.

2. Editorial Secretary (for the Judicial Commission of the International Committee on Systematic Bacteriology). 1971. Minutes of meeting of the Judicial Commission, Mexico City, Mexico. Int. J. Syst. Bacteriol. 21:100-103.

3. Editorial Secretary (for the Judicial Commission of the International Committee on Systematic Bacteriology), 1974. Minutes of meeting of the Judicial Commission, Jerusalem, Israel. Int. J. Syst. Bacteriol. 24:379.

4. International Code of Nomenclature of Bacteria. 1966. Int. J. Syst. Bacteriol. 16:459490.

5. Molisch, H. 1907. Die Purpurbakterien nach neueren Untersuchungen. G. Fischer, Jena.

6. Pfennig, N., and H. G. Trüper. 1969. Proposal to declare Rhodopseudomonas palustris and Chloropseudomonas ethylica as nomina conservanda. Int. J. Syst. Bacteriol. 19:153-154.

7. Van Niel, C. B. 1944. The culture, general physiology, morphology and classification of the non-sulfur purple and brown bacteria. Bacteriol. Rev. 8:1-118.

\section{Opinion 50 \\ Conservation of the Epithet fermentum in the Combination Lactobacillus fermentum Beijerinck}

\begin{abstract}
The epithet fermentum in the combination Lactobacillus fermentum Beijerinck has been conserved by the Judicial Commission of the International Committee on Systematic Bacteriology.
\end{abstract}

Rogosa and Hansen (4) note that the validity of publication of Lactobacillus fermentum Beijerinck (1) may be questioned, but the name is widely used for bacteria similar to Betabacterium longum Orla-Jensen (3).

They request conservation of Lactobacillus fermentum on grounds of stability of nomenclature and propose Orla-Jensen's strain 28 (=ATCC 14931) of Betabacterium longum
Orla-Jensen (3) as the neotype strain of $L$. fermentum. The Judicial Commission has acceded to this Request (reference 2, Minute 13) and issues the following Opinion.

Opinion 50. The species name Lactobacillus fermentum Beijerinck 1901 shall be held to be validly published by Beijerinck 1901 as the name of a bacterial species, and the epithet fermentum ' in the combination Lactobacillus 
fermentum Beijerinck 1901 is conserved over the epithets in all other synonyms. The neotype strain of Lactobacillus fermentum is ATCC 14931.

\section{LITERATURE CITED}

1. Beijerinck, M. W. 1901. Sur les ferments lactiques de l'industrie. Arch. Néerl. Sci. Ser. 2 6:212-243.
2. Editorial Secretary (for the Judicial Commission of the International Committee on Systematic Bacteriology). 1974. Minutes of meeting of the Judicial Commission, Jerusalem, Israel. Int. J. Syst. Bacteriol. 24:379.

3. Orla-Jensen, S. 1919. The lactic acid bacteria. Andr. Fred. Host. \& Son, Copenhagen.

4. Rogosa, M.; and P. A. Hansen. 1971. Nomenclatural considerations of certain species of Lactobacillus Beijerinck. Request for an Opinion. Int. J. Syst. Bacteriol. 21:177-186.

\section{Opinion 51 \\ Conservation of the Epithet fortuitum in the Combination Mycobacterium fortuitum da Costa Cruz}

The epithet fortuitum in the combination Mycobacterium fortuitum da Costa Cruz has been conserved by the Judicial Commission of the International Committee on Systematic Bacteriology.

Runyon (4) has drawn attention to the confusion over the name Mycobacterium ranae Bergey et al. 1923 (1), which appears to have priority over the widely used name Mycobacterium fortuitum da Costa Cruz 1938 (2) (type strain: ATCC 6841). He asks for conservation of the epithet fortuitum on the grounds of stability and because $M$. ranae is a nomen ambiguum. The Judicial Commission has acceded to this Request (reference 3, Minute 17 ), and issues the following Opinion.

Opinion 51. The specific epithet fortuitum in the name Mycobacterium fortuitum da Costa Cruz 1938 is conserved against the epithet ranae in the subjective synonym Mycobacterium ranae Bergey et al. 1923 and against the specific epithets in the names of all objective synonyms of Mycobacterium fortuitum and Mycobacterium ranae. The type strain of
Mycobacterium fortuitum is ATCC 6841.

\section{LITERATURE CITED}

1. Bergey, D. H., F. C. Harrison, R. S. Breed, B. W. Hammer, and F. M. Huntoon. 1923. Bergey's manual of determinative bacteriology, 1 st. ed. The Williams and Wilkins Company, Baltimore.

2. da Costa Cruz, J. 1938. Mycobacterium fortuitum um novo bacilo acido-resistente patogenico para o homen. Acta Med. (Rio de Janiero) 1:298-301.

3. Editorial Secretary (for the Judicial Commission of the International Committee on Systematic Bacteriology). 1974. Minutes of meeting of the Judicial Commission, Jerusalem, Israel. Int. J. Syst . Bacteriol. 24: 379.

4. Runyon, E. H. 1972. Conservation of the specific epithet fortuitum in the name of the organism known as Mycobacterium fortuitum da Costa Cruz. Request for an Opinion. Int. J. Syst. Bacteriol. 22:50-51. 